\title{
Debt Relief Reforms are not Enough to Alter the Relations of Inequality and Harm Reproduction: The Case of Educational Debt and the Need for Structural Reconstruction
}

\author{
Gregg Barak ${ }^{1}$
}

Accepted: 10 November 2020 / Published online: 2 January 2021

(c) Springer Nature B.V. 2021

\begin{abstract}
In the contemporary age of financialization, more and more citizens of the world are living in debt bondage and finding themselves subject to those financial institutions that are endangering the global political economy. At this turning point in global capitalism, even if the "one percent" provided "clean slates" for the debtors of the world, which has occurred many times in human history, the current economic polarization will continue to intensify so long as the contradictions of unsustainable capital accumulation are not resolved. In order to avoid a futuristic neo-serfdom, where people are not tied to the land, but are free to live wherever, though they are unable to make ends meet anywhere, structural reconstructions of our political economies are necessary. Using higher education and the student-loan debt crisis in the United States as its focus, this article makes the case for student relief rather than for student distress, especially for marginalized consumers. This investigation is not about state-financial criminality per se. More appropriately, it is about social harm in the tradition of zemiology.
\end{abstract}

\section{Introduction}

The level of outstanding federal and private student-loan debt in the United States (US) has increased sixfold since 2003. By June 30, 2019, this debt stood at more than US\$1.6 trillion-more than doubling the US\$720 billion debt total only one decade earlier. As Susan Carlson (2020) demonstrated recently, the unprecedented level of higher education debt and the intergenerational social harm that it generates may be linked to stateroutinized policies of neoliberalism, disinvestment in the commons, and privatization. These fiscal policies of austerity and the shift away from higher education as a government-financial public good to higher education as a commodity financed by individual debt began in the early 1980s, when the contradictions of stagflation-high inflation and

Gregg Barak

gbarak@emich.edu

1 Department of Sociology, Anthropology, and Criminology, Eastern Michigan University, Ypsilanti, MI, USA 
high unemployment-that emerged from the oil crises in the 1970s resulted in a combination of lower demand and lower commodity prices, as well as large deficits in the payment balance accounts of several developing and developed countries. In response, nations like the US have been reducing their social spending and infrastructure development as part of an adjustment process to capital accumulation, which has had negative social effects across society, especially for the growing numbers of marginalized people.

As the Editorial Board (2020: 2) of The New York Times wrote in its Sunday Review section on July 5, 2020: "Over the past four decades, American workers have suffered a devastating loss of economic power, manifest in their wages, benefits and working conditions." During the same period, however, the annual economic output of the US has almost tripled. For example, in the "nation's slaughterhouses, workers in 1982 made on average \$24 an hour in inflation-adjusted dollars"; today, the "average meatpacker processes significantly more meat-and makes less than \$14 an hour" (Editorial Board 2020: 2). While weekly wages have been stagnating since the late 1970s, the difference in capitalist labor expenses has been shifting from the workers to the owners, and now tops US\$1 trillion annually. On top of this "wage theft," the Economic Policy Institute has estimated that "employers illegally deprive workers of more than $\$ 50$ billion in wages each year by underpaying them or requiring unpaid work; violators are rarely punished" (Editorial Board 2020: 2; see also Leighton 2018).

Presently, and for the foreseeable future, these contradictions of wealth accumulation, propelled globally by a combination of finance capital and unsustainable debt, cannot be resolved by indebtedness forgiveness, as the roots of economic polarization, social inequality, and racial injustice lie elsewhere. Thus, my contention, here, is that without other structural reforms in the prevailing arrangements of economic, political, and social inequality, such as reinstituting a progressive tax system reminiscent of the postwar 1950s, overturning the Supreme Court's ruling in Citizens United v. Federal Election Commission, 558 U.S. 310 (2010), or passing an Equal Rights Amendment for $\mathrm{LGBT}+$, then erasing educational debt or creating clean educational slates and Jubilees for students will not be enough to make a substantial difference in long-term inequality. While such measures might have the effect of curbing debt bondage and providing temporary relief from the disproportionate negative impact that these financial practices have on the poor (Harris et al. 2010), much more reconstruction of our political economy is required. In the meantime-and in the short term - the targeted cancelation of educational debt could reduce some of the overall harm, while providing some relief for those people most negatively impacted by these policies of privatization.

Except for home mortgage borrowing, student loans topped all other sources of debt held by residents of the US, including car loans and credit cards. For financial perspective, this huge figure now exceeds the market value of Boeing, Coca-Cola, General Electric, McDonalds, Starbucks, and Walt Disney combined (Elias 2020). By early 2020, some 45 million borrowers shared this colossal sum of an ever-expanding amount of student debt (Troop et al. 2020). Back in 2019, Trevor Noah, host of The Daily Show, described college debt as the new herpes: "Almost everybody has it. It stays with you your whole life. And eventually, you're gonna have to tell your fiancé about it" (The Daily Show 2019). Seriously though, for the "noncompleters, those who dropped out of college, or even people who graduated but then suffered unexpected medical or financial calamity, even a small amount of debt can be paralyzing." On the other hand, for those "borrowers who can afford the monthly payments, educational debt is just another part of the price of admission to the [shrinking] middle class-even if they never entirely pay it off"' (Troop et al. 2020). 
With respect to the growing economic polarization or financial inequality found at the end of the second decade of the twenty-first century, the more affluent the family and the bigger the student-loan balances, the greater the likelihood that these loans would pay off as an investment for these graduates because they had access to the high incomes. Conversely, those people whose families reported annual incomes of US\$30,000 or less held nearly half of the college debt. These borrowers also had the smallest loan balances and yet they were more likely to default on their loan repayments. The loan default rates have not only correlated with socioeconomic status, but also with racial groupings. For example, compared to other racial and ethnic groups, Blacks, including those who have graduated from college, were more likely to default on their loans. According to the Center for American Progress, "about one in three black borrowers who began college during the 2011-12 academic year defaulted on their student loans within six years, a rate two and half times that of their white peers" (Troop et al. 2020).

Educational debt is part of a larger matrix of debts - consumer, corporate and nationalthat runs throughout the global economy. Together, these accumulations of ever-expanding debt are also capturing and driving international political economies. Most importantly, the primary interest rates since the Wall Street meltdown of 2008 have remained low, creating a debt-financed boom of cheap credit, which has prolonged an overgrowth of debt as compared to subpar growth of both the Gross Domestic Product (GDP) and worldwide trade. Accordingly, we may or may not be on our way to the next global economic meltdown because of our debt-driven economies and the creation of endogenous monies from banks lending credit primarily to buyers of real estate, education, and other assets. These types of lending policies that appeal to future prosperity have historically spawned repeated bubbles that burst sooner or later. As Steve Keen (2017) contends in Can We Avoid Another Financial Crisis, the reality has been that the virtues and vices of financialization have turned Southern Europe, the United Kingdom, and the US into zombie-capitalist economies of unleashed monetary speculation.

Moreover, as the debt to GDP ratios rise or as the net effects of private debt grows faster than the GDP, the problem of "debt inflation" worsens, the inability of borrowers to pay back their unpaid debt to creditors increases, and the dollars for spending on consumer goods and services contract as only about one-third of workers' nominal wages will be available for these purposes. Given the more negative global picture and economic climate described below, the burning and yet often unasked question remains: how much longer can credit be extended to consumers, to corporations, to states, and to nations that all share in common the inability to pay off their debts? In part, that answer depends on the global economy; in part, that answer depends on how long the US Federal Reserve will continue to green light the printing of money.

This article on educational debt relief is not framed from the perspective of a financial or state-financial crime because these loans typically conform to the prescribed legal specifications between the contracting parties. On the other hand, in the arena of social capital, the way these loans play out are responsible for human injuries and disadvantages, especially among low-income families. Therefore, this discussion on educational debt may be appropriately framed within the tradition of zemiology or the study of social harms (Hillyard et al. 2004). While I focus on educational debt, student austerity, and socioeconomic inequality in this article, I could have examined marginal experiences in relation to policing for profits, the privatizing of criminal justice services, the processing of debts, fees and fines, or the inability of punished offenders-debtors to pay for their own post-incarceration services (Council of Economic Advisors 2015; Harvard Law Review 2015). The rest of my discussion unfolds as follows: First, I locate indebtedness in the US in the context of 
the Great Recession and finance capitalism. Next, I present an overview of the educational debt crisis in the US. From here, I provide a brief history of debt forgiveness. Finally, I address the question of what is to be done.

\section{US Indebtedness in the Age of Finance Global Capital}

In the decade following the 2008 financial meltdown, global debt rose $50 \%$. As of June 2018, corporate, government, and household indebtedness totaled US\$178 trillion according to figures provided by S\&P Global Ratings. This "expansion was especially acute at the government level, which stood at $\$ 62.4$ trillion, or 77 percent higher than it did before the public borrowing binge began" (Cox 2019). At 10:13 PM (EST) on March 5, 2020, the outstanding public debt of the US was US\$23,461,200,000,000 according to the US National Debt Clock. This meant that every person in the US owed US\$71,217 on that day for their share of the public debt. This says nothing about individual family or household and corporate debts-or the interest accruing from these loans. For example, the non-corporate debt of 2017 would have added around US\$15 trillion broken down as household (including mortgage) at US\$12.73 trillion, credit cards at more than US\$1 trillion, and student loans at US\$1.3 trillion.

Contemporary deficits in the US are caused primarily by voluminous military budgets and by such predictable structural factors as an aging baby boom generation, rising costs of healthcare, and a tax system that brings in less money than the government spends. With respect to our nation's future fiscal and economic stability, healthcare is a critical issue as it currently represents one-fifth of the entire US economy. As most people are aware, US healthcare is the most expensive in the world-more than double the costs of other developed nations - and, yet, with poorer overall health outcomes. The healthcare system in the US is also the second fastest growing part of the federal budget, exceeded only by the interest payments on the debt made to service the previous borrowing. Nevertheless, with the exception of Bernie Sanders, none of the other twenty-five candidates competing for the 2020 presidential nomination of the Democratic Party, or any politician from the Republican Party, was ready at the time to join the rest of the advanced nations of the world: by creating a Medicare for All, single-payer, national health insurance program to provide everyone in the US with comprehensive coverage, free at the point of service. Even with the COVID-19 pandemic and the enormous health care costs and deaths experienced by this crisis so far, there has not yet been a shift politically to provide universal health care in the US.

When contextualizing the state of global capital, most economists agree that the complexities of forces shaping macroeconomic institutions are a product of the fact that the rates of output growth have been declining worldwide. In part, this contraction has been a legacy of both the eurozone (or euro area) and the supranational economic crises still prevalent in most countries to this day. In part, these debtor economies have been on the rise for the past two decades. Their high levels of debt—public, corporate, and household—continue to impact spending and growth, as well as failed and nonperforming loans, and to limit the credit supply for new borrowers. Similarly, the declining consumption worldwide of goods and services that indeed threatens the exponential expansion of capital accumulation and reproduction in advanced economies were also occurring before the global economic crisis made them worse by depressing investment lending and by weakening the expansion of productivity (Barak 2017). 
In emerging markets, these effects have been even more pronounced, especially where aging populations, lower capital accumulation, and slower productivity growth are combining to foreshadow a weaker overall potential for future sustainable expansion. In a few words, growth or the lack of growth is uneven, at best, and catastrophic, at worst. In market capitalism, during ordinary times, winners and losers are created in relation to larger monetary movements, such as what the relative prices and exchange rates between the dollar, euro, and the yen are, or when the international prime borrowing and other benchmark interest rates are established, or whether the price of oil or corn is increasing or decreasing. During extraordinary times, winners and losers have often been established in relation to debt crises and to central banks' responses to these crises. For example, this was the case when key financial institutions worldwide in response to the ripple effects of the Wall Street implosion spent more than US\$10 trillion to stimulate their economies.

This type of economic stimulation created a tidal wave of cheap money, which became the ticket for propping up and sustaining growth in many countries, while reducing unemployment and staving off, if not preventing, fiscal panics. Nevertheless, following the Great Recession (2009-2014), half of the European nations experienced zero growth in their GDPs. Turning to the Global South, as far back as 2015 and at least through 2017, Brazil, with the largest economy in the hemisphere, was experiencing negative GDPs. And after a decade of depression, Argentina, with the second largest economy in that region of the world, which had temporarily improved its GDPs (according to countryeconomy.com), posted GDPs from 2016-2019 as follows: $-2.1 \%, 2.7 \%,-2.5 \%$, and $-1.1 \%$. Perhaps more disappointing than the lack of growth in global GDPs has been the underperformance in the growth of global trade. For example, the International Monetary Fund (IMF) estimated that world trade volumes would grow at an annual average rate of $5.1 \%$ for the years 2011 through 2016. The actual growth rates for those years, however, were about $60 \%$ of that estimate or $3.2 \%$ per year. And, after the above-average trade growth of $4.6 \%$ in 2017 , the rates in 2018 and 2019 slowed respectively to $2.9 \%$ and $2.6 \%$.

Exacerbating the slowdown in global economic growth and outright stagnation in some geographical locales is the increasing competition of monopoly capitalism, coupled with the geopolitical and neoliberal economic policies of austerity and privatization that have been fueling the "race to the bottom" worldwide between national economies. Furthermore, the developed nations from around the world are now heading towards irregular economies. For example, the forecast for the US is that $50 \%$ of the labor force will be dependent on uncertain or contingent work by 2025. Increasingly, these workers will have no predictable earnings, hours, or benefits. This rapidly growing group of workers now include adjunct faculty at universities, beauticians, child care workers, independent journalists, Lyft drivers, software programmers, and stenographers. Of course, irregular economics and contingent workers will only depress consumer demand and slow down economic growth and trade further, as earners and borrowers find themselves increasingly on their own for survival-bearing most, if not all, of the risks associated with a changing global political economy.

These forecasts were pre-COVID-19. The global pandemic has been hastening and intensifying the internal contradictions of capital-debt accumulation. Some economists estimate that after the COVID-19 global crisis has abated, it may take as long as two decades before the global deflationary impact on the world economies have been fully weathered (Friedman 2020). After all, it took a decade for the US to recover from the financial ground lost to the Wall Street implosion of 2008, and those economic losses were about half of what the forecasted pandemic losses could be. 


\section{The Educational Debt Crisis in the US and the Need for Student Relief Rather than Student Distress}

In 2013, for a student-loan debt of US\$26,000, at an average interest rate of $6 \%$ compounded yearly using the standard ten-year payback plan for federal loans, the total cost payments for that debt came to about US $\$ 44,000$ or some US $\$ 500$ per month for 120 months. Naturally, educational debt costs former students time in savings as well as in interest accruement. Indebtedness also pushes back when and whether former students can purchase their first home, start a family, open a small business or have access to capital. Moreover, when parents have co-signed to secure these loans and their children may have defaulted for whatever reasons, parents' social security retirement checks may be garnished as repayment for their children's outstanding debt. As Andrew Ross argued in Creditocracy and the Case for Debt Refusal (2014), for these casualties of mass default, it amounts to a form of punishment for low-income families.

In the decade following the Great Recession, the doubling of student-loan debt can be attributed "to a sharp decline in state support for public colleges and a corresponding rise in tuition. State spending per student dropped by 24 percent from 2008 to 2012" and "the share of per student funding that came from tuition rose to 47 percent in 2012 from 36 percent in 2008" (Troop et al. 2020). Student loan default rates also increased in the wake of the recession, with borrowers from low-income families experiencing the steepest decline in repayments. In response, five income-driven Federal Student Loan Repayment Plans were established capping monthly payments as low as at $10 \%$ of a borrower's discretionary income. In recent years, these plans have grown in popularity despite their bureaucratic complexities as an alternative to fixed payment plans, constituting, by the end of 2017 , nearly half the volume of direct student loans. Regardless, for "those with low incomes, the monthly payments often don't cover the accruing interest, so the borrowers see debt balances rise" (Troop et al. 2020).

For the past couple of decades, colleges have become less affordable just as they have become increasingly more important for maintaining or improving one's economic prospects. The federal financial student aid website (https://studentaid.gov/) reported in 2016 that the expected family contributions were much less than the bills students actually faced (Goldrick-Rab 2016). This means that those without family wealth to support their education-low-income students, minorities, and first-generation immigrants-must work more hours and/or take out more loans, impacting their GPAs, the time to completion of their degrees (as well as whether they complete their degrees), and their future life choices.

In the scheme of things, two-year community colleges are relatively an affordable way for a wide range of people to get, or start, a college degree. A survey of 33,000 community college students across twenty-four states, however, found that about half of community college students were "housing insecure"-meaning that they had an inability to pay rent or needed to move frequently, as in "couch surfing" (Goldrick-Rab et al. 2017: 11). Fourteen percent were homeless, with $4 \%$ saying they had slept in an abandoned building or car. In addition, the survey found that about one-third of community college students had food insecurity, with $36 \%$ answering "yes" to the question: "Were you ever hungry but didn't eat because there wasn't enough money for food?" (Goldrick-Rab et al. 2017: 12).

Students who are hungry are less likely to be engaging fully with class material. Many are working long hours at low wage jobs with unfavorable hours, which makes them too tired to study and attend classes on a regular basis. Work and class schedules often conflict. These and other factors make successful completion of the degree or transfer to a four-year 
college less likely. For example, a study of 3000 undergraduates found that even when students successfully complete a four-year degree, they often had to go to great lengths to find money, which meant "a lower likelihood of participating in extracurricular activities, visiting professors during office hours, and spending time on campus" (Goldrick-Rab 2016: 33). In turn, with fewer opportunities to build relationships and social networks, their loaninvestments are less likely to bring strong returns on their college degrees.

In contrast, families with some wealth can make contributions that can confer a number of advantages. Family wealth expands the options for students to include wider geographical areas with more economic opportunities which, in turn, create possibilities of attending more expensive, elite educational institutions. Having good and secure housing does not make college easy, but it does remove several formidable barriers. The same can be said of reduced pressure to work long hours at low wage jobs-or not having to confront the decision about whether to drop out or suspend one's studies because of mounting debt. Finally, wealthier families have debt amounting to around $10 \%$ of their income as compared to low-income families whose mounting debt approximates $70 \%$ of their income. These lower levels of debt put fewer constraints on life after a bachelor's degree, meaning more opportunities to pursue graduate school or additional training, or to move away from parents and into a rental property with a partner, or to start saving for a house and building one's own wealth.

\section{A Profile of Student-Loan Debt in the US}

At the end of 2017, the demographics of indebtedness for almost 45 million people was derived primarily from Jacquelyn Elias (2020) in her article published by The Chronicle of Higher Education as follows:

- Parents hold only about $6 \%$ of the total outstanding debt; their children hold the other $94 \%$.

- The largest portion of outstanding federal student loan debt was incurred at public institutions, followed by private nonprofit and then private for profit.

- While less of the debt was incurred at private nonprofit institutions versus public ones, borrowers from these institutions hold more debt on average (public $=\mathrm{US} \$ 25,676$; private nonprofit $=\mathrm{US} \$ 36,897$; for profit $=\mathrm{US} \$ 20,869$ ).

- Distribution of debt and borrowers by debt size: while the majority of borrowers hold less than $\$ 20,000$ in debt, most of the federal direct loan debt comes from loans greater than $\$ 60,000$; just $16 \%$ of federal student-loan borrowers hold $55 \%$ of the debt.

- Nearly half of the outstanding federal debt is held by borrowers who reported their family incomes to be US\$30,000 or less annually.

- Pell Grant recipients hold $60 \%$ or US\$870,400,000,000 of the outstanding federal debt. $^{1}$

- $\quad 19.7$ million borrowers who did not complete their degrees hold $31 \%$ of the outstanding federal debt or US $\$ 457,000,000,000$.

\footnotetext{
${ }^{1}$ A Pell Grant is a federal grant typically awarded to undergraduates at colleges, universities, and career schools.
} 
- Share of debt by borrower's income percentile: while outstanding debt is distributed across all income percentiles, the largest portion is held by those with a household income above the national average median—or between US\$50,000 and US $\$ 100,000$.

- $\quad$ Sixty percent of the student debt or US\$913,550,000,000 comes from households that have at least a bachelor's degree.

- The breakdown of student loan share by type of education: $64 \%$ for a bachelor's degree; $23 \%$ for associates; $21 \%$ for masters or doctorates; $15 \%$ for certificates, and $10 \%$ for professional doctorates.

- $\quad$ Share of borrowers by gender: between 2009 and 2019, 61\% of borrowers were female even though women represented only $57 \%$ of students; $39 \%$ of borrowers were male, which represented $43 \%$ of students.

- Share of borrowers by race: White people account for more than $58 \%$ of student-loan borrowers; Blacks $=19 \%$, while representing $12 \%$ of population; Hispanic $=17 \%$, while representing $16 \%$ of population; mixed races $=2 \%$; other $=6 \%$.

- A Federal Reverse Board survey of household economics and decision-making found that one in three respondents said they were "finding it difficult to get by" or "just getting by."

- $\quad$ Share of delinquent debt in comparison with other debt: mortgage $=1 \%$; home equity line of credit $=2 \%$, credit card $=5 \%$; student loans $=9 \%$; other $=5 \%$.

- Among all types of household debt, repayments on student loans are most likely to be at least ninety days late; at the end of 2017 , the balance on $58 \%$ of the outstanding debt or US\$807,300,000,000 stayed the same or increased from the previous quarter.

- At the end of 2017, around $9 \%$ of the total outstanding debt was in default, representing one out of every ten borrowers.

- Defaulted federal direct loans by family income: nearly $70 \%$ of defaulted direct loans came from borrowers who reported family incomes of less than US $\$ 30,000$.

- Defaulted borrowers by debt size: With respect to those people whose federal direct loans were greater than 270 days delinquent, which is when a loan is considered to be in default, about one in five owed less than $\$ 5,000$ while almost two-thirds of these borrowers owed less than US\$20,000.

- Share of Defaulting by race: over half of Black respondents who took out loans reported defaulting within twelve years of starting college, compared with $23 \%$ of White borrowers; American Indian or Alaska $=43 \%$, mixed race $=41 \%$; Hispanic $=39 \%$; Other $=28 \%$; Native Hawaiian or Pacific Islander $=13 \%$; Asian $=12 \%$.

\section{Debt Forgiveness: A Brief Historical Perspective}

One party's debt is another party's saving or credit. A bank deposit is a debt to the depositor. Money is a government or bank debt. In the contemporary era, most of the real debt from the $99 \%$ is the interest owed on their indebtedness to the "one percent." As noted above, debt forgiveness or relief is also referred to as "clean slates" or Jubilees and, in the Bible, as the Day of Atonement when all of the property and persons that had been taken by others for unpaid debts were to be returned to their original families. Everyone 
previously indebted was to be released from that debt and able to start over again with a clean slate. The royal practices of Jubilee date as far back as the Bronze Age. Beginning in the third millennium BCE, Sumerians, Babylonians, and finally Egyptians in 197 BCE annulled debts so as to save their societies "from being torn apart by transferring land and personal liberty to creditors" (Hudson 2017: 59). Jubilee Year-or the forgiving of noncommercial debt once every fifty years-was also at the core of Judaic Law.

For more than half of recorded history, from $3000 \mathrm{BCC}$ to $1000 \mathrm{CE}$, "religions sanctified the cancellation of personal debt so as to prevent debt bondage and widespread forfeitures of self support land to foreclosing creditors" (Hudson 2017: 206). Thus, it was normal for new rulers to proclaim "clean slates" to annul personal debts owed to the palace, its collectors and other creditors. Humanitarian treatment of debtors was also the norm from ancient Mesopotamia through Solon's reforms in Greece (594 BCE), Judaism's Mosaic law, Jesus' announcement that he would exceed the liberation of a Jubilee Year (Luke 4:18), and Islamic sharia law banning the charging of interest. The goals of these royal proclamations, starting with Hammurabi's Babylonian dynasty in the second millennium BCE to the Biblical Jubilee Year was threefold: "to wipe out personal debts...liberate bondservants to return to their families, and [to] restore land and crop rights that had been forfeited to creditors" (Leviticus 25: 8-13).

With some exceptions, modern debt cancelations or "clean slates," such as the 1948 Allied Monetary Reform in Germany, are limited to personal or corporate bankruptcies on a case-by-case basis. As Hudson (2017: 59) puts it, in contrast "to ancient society's idea of circular time-with clean slates to restore economic balance when debts grew too burdensome-today's concept of linear time treats the debt build up as cumulative and irreversible. The result is that without debt cancellations economies evolve into oligarchies that claim their takeover is "natural' and thereby morally justified." In the process, those not belonging to the "one percent" have to work increasingly longer to carry the debts they need in order to own their homes, obtain education, and meet other basic needs. These contemporary debtors are a "counterpart to medieval serfdom," as Hudson (2017: 89) proclaims - "a looming epoch of debt peonage for entire economies"- not unlike in Ancient Greece and Rome, where hereditary lordships headed by the financialized "one percent" held the $99 \%$ in deepening debt.

\section{What is to be Done?}

According to a survey conducted in the fall of 2019 by the Pew Charitable Trusts and cited in Troop and colleagues (2020), Americans are divided on this issue. On the one hand, eight in ten respondents thought that the government should make it easier for student borrowers to repay their student loans. On the other hand, nearly the same percentage of respondents thought that student borrowers should make repaying their loans a greater priority. These two responses are not mutually exclusive, as $83 \%$ of those responding to the survey believed that both the borrowers and US government should take more action to ease the process of loan repayment (Troop et al. 2020).

More generally, the public has come to accept the bailing out of businesses and banks, if not the bailing out of ordinary people. The issue, however, is really one of bailing out individual borrowers and indebted economies because, as Saint Simon articulated some two centuries ago in France, the logic and policy of borrowers paying back their loans should always be dependent on their capacities to do so. Because these capacities are no 
longer viable for millions of borrowers worldwide, Keen (2017) has proposed a Modern Debt Jubilee, essentially swapping equity for debt. In other words, Keen's (2017) solution to the growing debt crisis is for banks to take an equity position in their clients, so that payments to lenders could rise and fall in keeping with money gained or lost. As a transition from today's debt stagnation, Keen (2017) suggests that central banks create a lump sum of money to be placed into everyone's bank account. Those with debt would be required to use their financial gift to pay down their debt; non-debtors would be allowed to keep their transfer payments so as not to reward debtors for their allegedly individualistic defaults rather than for their structurally caused financial downturns. Similarly, Michael Hudson (2017: 270) argues that what is at issue here "is whether debt-strapped economies will let themselves be driven into a new Dark Age of debt serfdom" or will they "be able to survive by freeing their economies from debt by enacting Clean Slates and restoring progressive tax policy"?

My contention is that a "clean slate" or some type of Jubilee, even periodic ones, for a growing number of permanent debtors living a postmodern form of debt bondage, would "free" them only temporarily from the underside of the current flows of financial speculation and capital expansionism, as the structural or contradictory forces of social inequality and capital accumulation, left unaddressed, will only continue to intensify. In short, if the trends in unsustainable economic expansionism and global warming and climate change are not transformed in relation to sustainable flows between different forms of capital and currency, then the societies of the world may very well find themselves slipping into the next age of "apocalyptic darkness." In the meantime, as the circular flow between producers and consumers in financial- and debt-driven economies continues to atrophy-and as money is siphoned off by both debt services and by government taxes - these reciprocal relations of expanding debt have a contracting effect on both domestic and international consumption.

Politicians are also divided on the matter of educational debt. In February of 2020, as part of a fiscal year 2021 budget proposal, Republican President Donald J. Trump unveiled his educational plan that would "end federally subsidized student loans, eliminate the beleaguered Public Service Loan Forgiveness program, place yearly and lifetime limits on Graduate PLUS and Parent PLUS loans, and fold the federal government's array of income-driven repayment plans into a single one" (Troop et al. 2020). The Trump Administration proposed plan would also raise the percentage of discretionary income that borrowers on income-driven plans must pay from the $10 \%$ that most current plans require to $12.5 \%$. At the same time, the plan shortens the payment terms for undergraduates to fifteen years while stretching the length of graduate student loans to thirty years.

On the other side of the aisle, candidates for the Democratic presidential nomination had proposed a range of alternatives for dealing with America's college debt and rising costs. For example, Joe Biden offered some modest adjustments to the existing system. He called for federal-state partnerships to provide more financial resources for community colleges and to make these two-year institutions essentially tuition free. His plan also would invest US\$18 billion in grants to Historically Black Colleges and Universities (HBCUs), Tribal Colleges and Universities, and Hispanic-serving institutions. As for the US\$1.6 trillion student-loan debt and the problem of the growing indebtedness crisis in American higher education, the former vice-president was conspicuously silent on the subject.

By contrast, Bernie Sanders' proposed College For All Act would provide at least US\$48 billion annually to eliminate tuition and fees for all students as well as providing all indebted student loans with “clean slates.” As Bernie's Official Website (2020) elucidated during the race for the Democratic nomination for president in 2020: 
Seventy-three percent of the benefits of cancelling all student debt will go to the bottom 80 percent of Americans, who are making less than $\$ 127,000$ a year. President Trump's tax cuts for the wealthy and big corporations cost more than $\$ 2$ trillion, 83 percent of which will end up going to the top 1 percent. Bernie believes that money would be better spent on freeing millions of hardworking people from the burden of student debt, boosting the economy by $\$ 1$ trillion over the next ten years, and creating up to 1.5 million new jobs every year. By canceling student debt, we will save the average student loan borrower around $\$ 3,000$ a year in student loan payments. That money will be freed up to spend on everything from housing to starting a business.

The four main components of Sanders' College for All included:

- $\quad$ Guaranteed tuition and debt-free public colleges, universities, HBCUs, Minority Serving Institutions and trade schools to all students regardless of income.

- Cancelation of all student loan debt for the some 45 million Americans who owe about US\$1.6 trillion and place a cap on student loan interest rates going forward at $1.88 \%$.

- An investment of US\$1.3 billion every year in private, non-profit historically black colleges and universities and minority-serving institutions.

- $\quad$ An end to equity gaps in higher education attainment and ensuring that students are able to cover non-tuition costs of attending school by: expanding Pell Grants to cover non-tuition and fee costs, and tripling funding for the Work-Study Program.

As indicated above, US educational debt is part of a larger matrix of indebtedness and policies of social disinvestment, as well as privatization, that helps to drive the global political economies of capital financialization. Accordingly, since the 1980s, both the global and US accumulation and distribution of wealth (and income) has become increasingly more unequal as the poor have become poorer and the medium income of the majority of workers has remained flat. Most governments faced with perpetual fiscal crises and rising indebtedness have continued to drain resources from the poor and others by way of welfare reform, privatization, and other austerity measures to compensate for lackluster growth.

At the same time, many of these countries, especially the US, have repeatedly given away hundreds of billions, if not trillions, of dollars to the rich and well-endowed corporations through esoteric tax sheltering techniques, lavish tax cuts, and a plethora of financial looting schemes sanctioned by the Federal Reserve, the Security and Exchange Commission, and the Department of Justice (Barak 2012). Consequently, for the past three decades, the majority of the American people has been struggling just to stay even economically while the working poor are simply falling further behind.

In conclusion, Bernie Sanders' "clean slate" or Jubilee, his cancelation of educational debt, and his free tuition for all, represent at least temporary relief and a reduction in some forms of harm production especially for marginalized people. In terms of what the US requires, however, Sanders' "Our Revolution" simply does not go far enough! Like the Black Lives Matter movement that has captured the popular imagination at this time, and like all those folks, including many police officers, that have been calling not only for the demilitarization and defunding of law enforcement, but also for "New Deal" style social policies to reinvest that unallocated money in the social commons and in those racially marginal communities who have been experiencing social and economic neglect since the 
1970s, we should all be reimagining how our health care, educational, and economic systems could be transformed as well.

In this historical moment, for example, even the World Economic Forum, a cosmopolitan body, has organized its January 2021 in-person and virtual twin summit, connecting key governmental officials with a global multistakeholder network of 400 cities from around the world, for a forward-oriented dialogue driven by the younger generation. The ideological theme of the conference is "The Great Reset" and the "About" page of the website (https://www.weforum.org/great-reset/) talks of more fair and sustainable economic and social systems. Catalyzed by the global pandemic health care crisis, the World Economic Forum advocates for a new social contract centered on human dignity, social justice, and societal progress that keeps pace with that of economic development (Strether 2020). Of course, without strong global social movements to push for these types of public agendas, the likelihood is very unlikely that the global business elites at Davos, Switzerland (where the World Economic Forum will be held) will address the fundamental contradictions of capitalist accumulation.

\section{References}

Barak, G. (2012). Theft of a nation: Wall Street looting and federal regulatory colluding. Lanham, MD: Rowman \& Littlefield.

Barak, G. (2017). Unchecked corporate power: Why the crimes of multinational corporations are routinized away and what we can do about it. New York: Routledge.

Bernie Sanders Official Website. (2020). https://berniesanders.com/.

Carlson, S. (2020). The U.S student loan debt crisis: State crime or state-produced harm? Journal of White Collar and Corporate Crime, 1(2), 140-152.

Council of Economic Advisers. (2015). Fines, fees, and bail: Payments in the criminal justice system that disproportionately impact the poor. December. Retrieved on November 6, 2020, from https://obama whitehouse.archives.gov/sites/default/files/page/files/1215_cea_fine_fee_bail_issue_brief.pdf.

Cowley, S. \& Silver-Greenberg, J. (2017). As paperwork goes missing, private student loan debts may be wiped away. The New York Times, June 17. Retrieved on November 6, 2020, from https://www.nytim es.com/2017/07/17/business/dealbook/student-loan-debt-collection.html.

Cox, J. (2019). Global debt is up 50\% over the past decade, but S\&P still says the next crisis won't be as bad. $C N B C$, March 12. Retrieved on November 6, 2020, from https://www.cnbc.com/2019/03/12/globa 1-debt-up-50-percent-since-the-financial-crisis-sp-says.html.

Elias, J. (2020). Who holds America's \$1.5-trillion student-loan debt? The Chronicle of Higher Education, March 3. Retrieved on March 4, 2020, from https://www.chronicle.com/interactives/who-holds-stude nt-debt.

Editorial Board. (2020). The Jobs We Need. The New York Times, June 24. Retrieved on November 6, 2020, from https://www.nytimes.com/2020/06/24/opinion/sunday/income-wealth-inequality-america.html.

Friedman, T. (2020). Full transcript: Thomas Friedman on the world after novel coronavirus pandemic. India Today, May 7. Retrieved on November 6, 2020, from https://www.indiatoday.in/e-conclave2020/story/full-transcript-thomas-friedman-on-the-world-after-novel-coronavirus-pandemic-16751 94-2020-05-07.

Goldrick-Rab, S. (2016). Paying the price: College costs, financial aid, and the betrayal of the American dream. Chicago, IL: University of Chicago Press.

Goldrick-Rab, S, Richardson, J., \& Hernandez, A. (2017). Hungry and homeless incollege: Results from a national study of basic needs insecurity in higher education. Wisconsin Hope Lab, March. Retrieved on November 6, 2020, from https://hope4college.com/wp-content/uploads/2018/09/Hungry-and-Homel ess-in-College-Report.pdf.

Harris, A., Evans, H., \& Beckett, K. (2010). Drawing blood from stones: Legal debt and social inequality in the contemporary United States. American Journal of Sociology, 115(6), 1753-1799. 
Harvard Law Review. (2015). Policing and profit: Developments in the law. Harvard Law Review, 128, 1723-1746. Retrieved on November 6, 2020, from https://harvardlawreview.org/2015/04/policing-andprofit/.

Hillyard, P., Pantazis, C., Tombs, S., \& Gordon, D. (Eds.). (2004). Beyond criminology: Taking harm seriously. London: Pluto Press.

Hudson, M. (2017). J is for junk economics: A guide to reality in an age of deception. New York: ISLET-Verlag.

Keen, S. (2017). Can we avoid another financial crisis? Cambridge, UK: Polity Press.

Leighton, P. (2018). No criminology of wage theft: Revisiting "workplace theft" to expose capitalist exploitation. In S. Bittle, L. Snider, S. Tombs, \& D. Whyte (Eds.), Revisiting crimes of the powerful: Marxism, crime, and deviance (pp. 188-201). Abingdon, Oxon, UK, and New York: Routledge.0.

Ross, A. (2014). Creditocracy and the case for debt refusal. New York: OR Books.

Strether, L. (2020). Can Davos Man Punch the "Great Reset" Button? Retrieved on November 27, 2020, from https://www.nakedcapitalism.com/2020/07/can-davos-man-punch-the-great-reset-button.html.

The Daily Show. (2019). Student Debt in the U.S. Reaches an All-Time High. July 25. Retrieved on November 27, 2020, from https://www.youtube.com/watch?v=k9q6JJT2WmE.

Troop, D., Leckrone, B., \& McLean, D. (2020). Unraveling the complexity of America's student-loan debt. The Chronicle of Higher Education, March 3. Retrieved on November 6, 2020, from https://www. chronicle.com/article/Unraveling-the-Complexity-of/248171.

Publisher's Note Springer Nature remains neutral with regard to jurisdictional claims in published maps and institutional affiliations. 